\title{
Rock magnetic properties, magnetic susceptibility, and organic geochemistry comparison in core LZ1029-7 Lake El'gygytgyn, Russia Far East
}

\author{
K. J. Murdock ${ }^{1}$, K. Wilkie ${ }^{1, *}$, and L. L. Brown ${ }^{1}$ \\ ${ }^{1}$ University of Massachusetts Amherst, MA 01003, USA \\ *now at: University of Toronto, Toronto, Canada \\ Correspondence to: K. J. Murdock (kmurdock@geo.umass.edu)
}

Received: 21 August 2012 - Published in Clim. Past Discuss.: 18 September 2012

Revised: 17 January 2013 - Accepted: 21 January 2013 - Published: 28 February 2013

\begin{abstract}
Susceptibility measurements performed on initial short $(\sim 16 \mathrm{~m})$ cores PG1351 taken from Lake El'gygytgyn exhibited a large range in values. This observation led to the suggestion of widespread magnetite dissolution within the sediments due to anoxic conditions within the lake. Rock magnetic properties and their comparison with magnetic susceptibility, total organic carbon (TOC), and bulk $\delta^{13} \mathrm{C}_{\text {org }}$ proxies in core LZ1029-7, taken from the same site as the previously drilled PG1351, provide an insight into the character of the magnetic minerals present within the lake and can further the understanding of processes that may be present in the newer long core sediments. Susceptibility measurements $(\chi)$ of discrete samples corroborate the two order of magnitude difference seen in previous continuous susceptibility measurements $(\kappa)$, correlating high values with interglacial periods and low values with glacial intervals. Hysteresis parameters indicate that the majority of the magnetic material to be magnetite of PSD size. TOC values increase while $\delta^{13} C_{\text {org }}$ values decrease in one section of LZ1029-7, which is defined as the Last Glacial Maximum (LGM), and help confine the age of the core to approximately $62 \mathrm{ka}$. Increases in TOC during the most recent glacial interval suggest increased preservation of organic carbon during this period. High TOC and low magnetic susceptibility during the LGM support the theory of perennial ice cover during glacial periods, which would lead to lake stratification and therefore anoxic bottom water conditions. Low temperature magnetic measurements confirmed the presence of magnetite, but also indicated titanomagnetite and possibly
\end{abstract}

siderite, rhodochrosite, and/or vivianite were present. The latter three minerals are found only in anoxic environments, and further support the notion of magnetite dissolution.

\section{Introduction}

Magnetic susceptibility is a widely used property that, in its most basic of magnetic inferences, gives some indication of the amount of ferromagnetic magnetic minerals, mainly the mineral magnetite. Magnetic susceptibility is a common measurement employed in paleoclimate reconstruction of terrestrial, marine, and lacustrine environments (Anderson et al., 2002; Chlachula et al., 1998; Demory et al., 2005; Evans and Rutter, 1998; Evans and Heller, 2001, 2003, and the references therein; Geiss and Banerjee, 1997; Langereis et al., 1997; Maher and Thompson, 1992; Maher, 2011; Nawrocki et al., 1996). Often, high values correlate to warm and/or wet periods whereas low values denote cold and/or dry periods (Vlag, 1999; Evans, 2003). However, in some cases, high susceptibilities signify cold, glacial periods while low values indicate interglacials (i.e. Alaska; Begét, 1996; Evans and Rutter, 1998; Evans and Heller, 2003). There is even evidence that within the same region, some lake sediments exhibit opposite magnetic susceptibilities for the same time frame (Tudryn et al., 2010). This correlation between climate and relative values of magnetic susceptibility can be made due to the nature of magnetic susceptibility: essentially, it is a measure of the amount of magnetic minerals within a 
sample, which can be related to erosional output from terrestrial sources. There are, however, caveats to what the source of the magnetic particles may have been, such as if it was a terrestrial source, secondary formation of minerals, or possibly biogenic in origin. This leads to the necessity of identifying the types, sizes, and distribution of magnetic minerals present within a location. Several other rock magnetic measurements can be made in order to clarify the identity and origin of magnetic particles, and therefore provide a more comprehensive understanding of lake conditions and from that climate conditions.

Lake El'gygytgyn, located in the Far East Russian Arctic, has provided and continues to provide a wealth of information for paleoclimate reconstruction over the past $3.6 \mathrm{Ma}$ (Melles et al., 2012). Magnetic susceptibility was one of the first properties to be measured on the initial short cores from 1998, later short cores from 2002, and the new long cores (315 m lake sediment) drilled in 2009. Susceptibility measurements showed an extreme range of values - in some cases two orders of magnitude (Nowacyzk et al., 2002); high and low values correspond to interglacial and glacial periods, respectively. Such high susceptibilities in the sediment - on the order of $10^{-4} \mathrm{SI}$ - can be attributed to the large amount of magnetite-bearing volcanic rocks surrounding Lake El'gygytgyn. Low values, however, are more difficult to explain. Nowacyzk et al. $(2002,2007)$ suggest the low susceptibility values indicate the dissolution of magnetite during glacial periods owing to a stratification of the lake with severely anoxic bottom water. This is a valid and probable theory for the range in susceptibility and has been suggested for other lake systems (Snowball, 1993). Nowaczyk et al. (2007) also suggest that dissolution occurs through most of the short cores, even during some interglacial periods, and that susceptibility is not a reliable indicator of terrestrial input.

Although the dissolution of magnetite would cause such fluctuations as seen in the susceptibility measurements of Lake El'gygytgyn, there are some questions left with this theory: if such a large amount of magnetite is being dissolved prolifically throughout the cores, where is the free iron in the lake? Also, the relationship with other climate proxies is not well defined, such as total organic carbon (TOC), which should have a near perfect anti-correlation with magnetic susceptibility. The 2009 drilling of Lake El'gygytgyn long cores presented a need for a more in depth study of magnetic properties of the short core LZ1029-7 drilled in 2003 in order to better understand the processes affecting the lake and also refine a series of measurements that will later be performed on the new cores. The magnetic data from LZ1029-7 was interpreted and compared to such proxies as TOC and bulk $\delta^{13} \mathrm{C}_{\text {org }}$ to gain a better understanding of lake conditions. This investigation was meant to serve as an initial study of magnetic parameters in LZ1029-7 to provide the basis for further in-depth examinations in the longer cores.

\section{Background}

Lake El'gygytgyn was formed as the result of a meteorite impact (Belyi and Raikevich, 1994; Belyi et al., 1994). The lake itself is approximately $12 \mathrm{~km}$ in diameter and $175 \mathrm{~m}$ deep. It is located in central Chukotka, northeastern Siberia, Far East Russian Arctic (Fig. 1a). Because of the location of Lake El'gygytgyn within this unglaciated region, it is theorized to be an ideal candidate for paleoclimate reconstruction due to the lack of ice sheet cover since its formation, thus providing a continuous terrestrial sedimentary record (Brigham-Grette et al., 2007). In 1998 the first international scientific expedition to the lake occurred as a result of collaboration between Russian, German, and US scientists (Melles et al., 2007). Two cores, PG1351 (12.7 m) and PG1352 (4.1 m) were recovered. A second expedition, in 2003, retrieved a multitude of samples including two cores, LZ1024 (16.37 m) and LZ1029-7 $(2.85 \mathrm{~m})$ - the latter being the core under study here - as well as other sediment, rock, and water samples (Fig. 1b). In early 2009, an international team of scientists, drillers, and ice engineers returned to Lake El'gygytgyn for an ICDP supported drilling project. Successful drilling operations recovered a composite core consisting of $315 \mathrm{~m}$ of lake sediment as well as $\sim 200 \mathrm{~m}$ of bedrock breccia from the meteor impact that created the lake (Melles et al., 2011, 2012).

\subsection{General geology}

Lake El'gygytgyn is located in a meteorite crater formed 3.58 $( \pm 0.04) \mathrm{Ma}$ (Layer, 2000), and has a diameter of $18 \mathrm{~km}$. Various igneous rocks, both extrusive and intrusive, surround the lake and provide the bulk of sediment input. Rock types, including rhyolite, andesite, granite, gabbro, basalt (flows and dikes), dacite, tuff, and combinations of those types, can be found in the area, most of which date to the Cretaceous period. The stratigraphy was described in detail by Belyi and Raikevich (1994). Geochemical analyses of the sediments provide evidence of significant amounts of aluminum, potassium, sodium, calcium, iron, magnesium, and titanium (Minyuk et al., 2007).

There are roughly 57 ephemeral streams draining into the lake basin from the surrounding catchment (Nolan and Brigham-Grette, 2007). These streams provide the main source of the water into Lake El'gygytgyn. There is one outlet, Enmyvaam River, located to the southeast. Due to the climate of the area, deep permafrost surrounding the lake prevents significant flow of groundwater. Therefore, the majority of water going into and coming out of Lake El'gygytgyn flows through the ephemeral streams and single out flowing river (Schwamborn et al., 2006; Federov et al., 2009, 2012; Wilkie et al., 2013).

Presently, lake freeze-up occurs in mid-October and remains ice covered through early to mid-summer (Nolan et al., 2002; Melles et al., 2007). Climate conditions during 

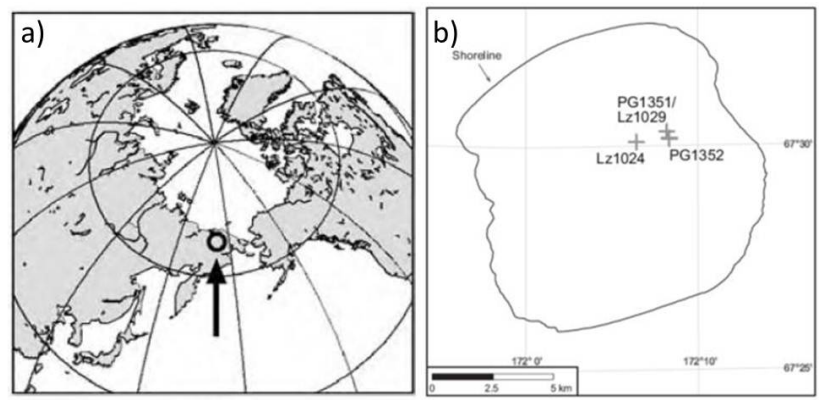

Fig. 1. (a) Location of Lake El'gygytgyn in Far East Russian Arctic, $67^{\circ} 30^{\prime} \mathrm{N}, 172^{\circ} 5^{\prime} \mathrm{E}$ (Nowaczyk et al., 2002). (b) Location of collected cores in Lake El'gygytgyn. Cores PG1351 and PG1352 were drilled in 1998, cores LZ1024 and LZ1029 were collected in 2003, and long cores were drilled in 2009 (not shown).

previous glacial periods have been theorized to produce perennial ice cover with virtually no significant time of icefree water at the lake (Nowaczyk et al., 2002; Melles et al., 2007). This ice-covered state would considerably limit the influx of terrestrial sediment and aeolian particles into the lake, even during summer months, though continuous deposition throughout the record precludes complete isolation.

\subsection{Previous magnetic analyses}

Previous magnetic investigations on short cores were performed by Nowaczyk et al. (2002, 2007), with paleomagnetic data from the forthcoming ICDP 5011 core (Nowaczyk et al., 2013). Magnetic susceptibility, natural remanent magnetization (NRM), characteristic remanent magnetization (ChRM), and hysteresis properties were measured on PG1351. One of the intriguing early observations on core PG1351 is the several order of magnitude range of the magnetic susceptibility. High susceptibilities can be explained with the erosional input of volcanic rocks surrounding the lake, with magnetite being the major magnetic contributor. Low susceptibilities, however, could not be explained by the dilution effect of large amounts of organic material and/or biogenic silica in comparison to magnetic materials (Nowaczyk et al., 2002).

Nowaczyk et al. (2007) provided a more accurate time scale for core PG1351 using magnetic susceptibility, TOC, $\mathrm{TiO}_{2}$, and biogenic silica. The earlier paper (Nowaczyk et al., 2002) based the age model on mostly infrared-stimulated luminescence (IRSL) and pollen, and only partially on magnetic susceptibility and its correlation to the GRIP ice record. It was clear from the first age model that more work was needed to better constrain the older parts of the core. Only magnetic susceptibility was useful for the age model and not paleomagnetic directions, since the first core only represented approximately $250 \mathrm{ka}$. The opportunity to reexamine the magnetic susceptibility to better pinpoint ages in the core allowed for its reassessment in relation to other proxies. Magnetic susceptibility was compared to several proxies
(TOC, $\mathrm{TiO}_{2}$, biogenic silica) in an effort to explain the large range seen in susceptibility. The working theory developed by Nowaczyk et al. (2002) for the particularly low susceptibilities is that during glacial times with perennial ice cover, Lake El'gygytgyn would have stratified, causing severe anoxia in the bottom waters. With so little oxygen, magnetite could then be dissolved, and thus the magnetic susceptibility values would become extremely low. $\mathrm{TiO}_{2}$ is typically used as a proxy for terrigenous input and should positively correlate to the magnetic susceptibility. However, in Lake El'gygytgyn it is not correlated and this has been interpreted as supporting evidence of magnetite dissolution during glacial periods due to severe anoxia.

\subsection{Microscopy}

In 2005, Richard Reynolds of the US Geological Survey in Denver, Colorado, prepared several samples of magnetic separates from LZ1029-7 for reflected microscopy work (R. Reynolds, personal communication, 2005). Preliminary observations of several of the samples indicated the abundance of very small angular magnetite particles in areas of high or relatively high magnetic susceptibility. There were also volcanic fragments - consistent with the parent rocks surrounding Lake El'gygytgyn - that contained tiny magnetite grains. A small amount of titanomagnetite and magnetite grains larger in size to the very small magnetite grains were observed. Three photomicrographs of samples taken from LZ1029-7 are shown in Fig. 2. Figure 2a shows a volcanic rock fragment approximately $80 \mu \mathrm{m}$ in length containing small magnetite (bright spots). Figure $2 \mathrm{~b}$ is of particular note as it shows a partially dissolved titanomagnetite grain with titanium oxide. The last photomicrograph (Fig. 2c) is an example of the very small angular magnetite grains $(\sim$ $14 \mu \mathrm{m})$ found in various sections of high susceptibility.

\subsection{Lake sediment core LZ1029-7}

The short core LZ1029-7 that is used in this study was drilled in 2003 at the same site as PG1351, drilled five years earlier, so as to repeat the upper $80 \mathrm{~cm}$ of core which had been subsampled in the field instead of keeping it in the core liner. Nine separate sections were drilled from the LZ1029 site using either a gravity corer or a piston corer. Five sections were sent to the University of Massachusetts Amherst for study biology of the fluff layer, organic and inorganic geochemistry, and pore water chemistry. The other four cores were sent to Leipzig University for physical properties, paleolimnology, and surface sediment composition. LZ1029-7 was one of the untouched percussion piston cores ( $2.91 \mathrm{~m}$ in length) sent to the University of Massachusetts Amherst for organic and inorganic geochemistry, and later provided subsamples for the magnetic data in this study. 

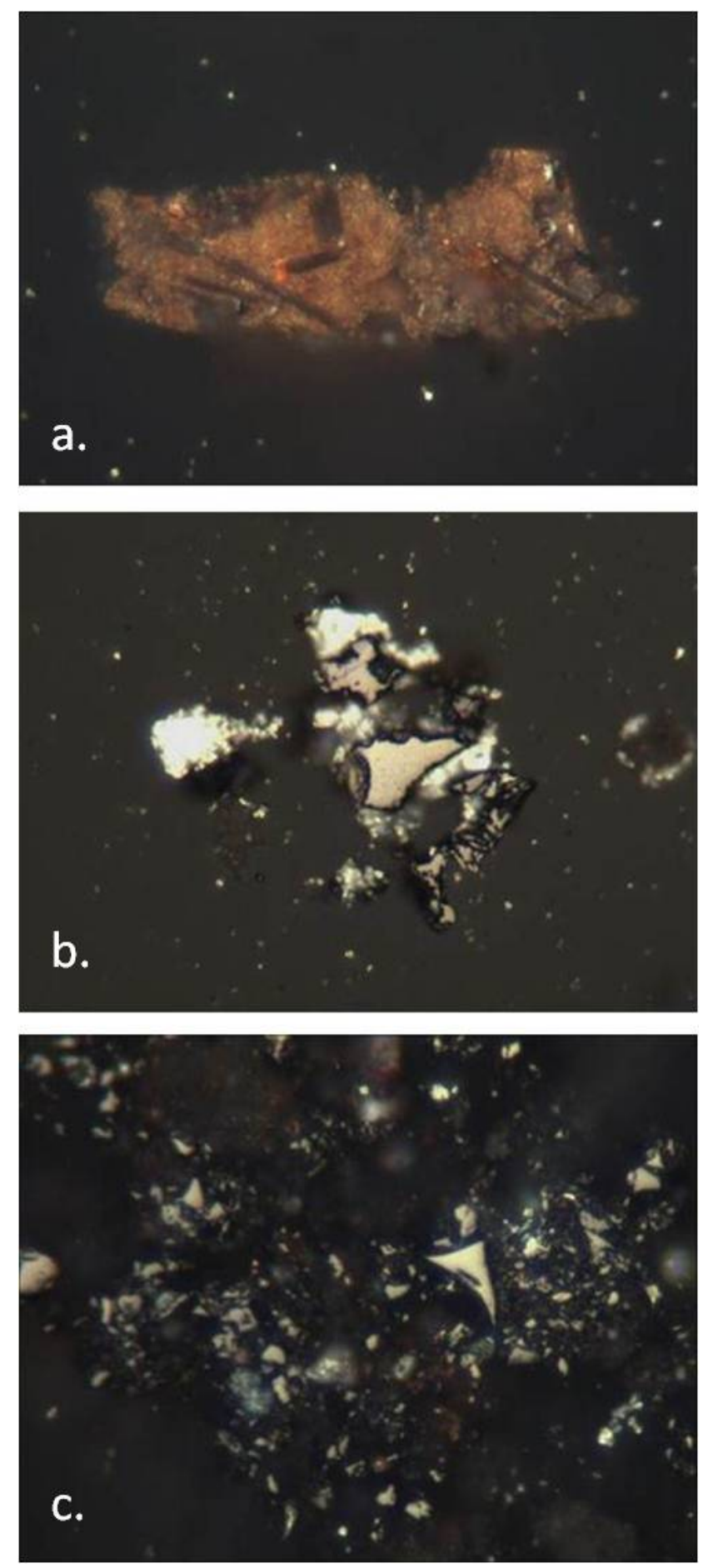

Fig. 2. Photomicrographs of LZ1029-7 of magnetic separates. (a) Volcanic rock fragment measuring approximately $80 \mu \mathrm{m}$ in longest dimension. (b) Partially dissolved titanomagnetite with precipitated titanium dioxide (bright white versus dull white) about $74 \mu \mathrm{m}$ along longest dimension. (c) Small, angular magnetite grains. Bright white triangular magnetite grain measures approximately $14 \mu \mathrm{m}$ along long dimension.

\subsection{Chronology}

Chronology for this core (Fig. 3) was established by correlation to sister cores LZ1029-5/8/9 and to core PG1351 based on sedimentology and stratigraphic markers (e.g. turbidites). Although laminations observed in other short sister cores (e.g. Melles et al., 2007; O. Juchus, V. Wennrich, and M. Melles, personal communication, 2009) were only weakly visible and/or absent in core LZ1029-7, similar trends in TOC $\%$ and bulk ${ }^{13} \mathrm{C}_{\text {org }}$ are present and were used to provide additional tie points and further constrain the age-depth model. Ages were calculated by linear interpolation between correlation tie points. The chronology for core PG1351 was derived by tuning the magnetic susceptibility record to Northern Hemisphere insolation, supported by the biogenic silica, TOC and $\mathrm{TiO}_{2}$ records as well as OSL dates yielding a basal age of $275 \mathrm{ka}$ (Nowaczyk et al., 2002, 2007; Forman et al., 2007; Frank et al., 2012). Development of an age model for LZ1029-7 sediments allows for direct comparison of multiple proxies both regionally and throughout the El'gygytgyn basin

\section{Methods}

\subsection{Rock magnetic measurements}

Samples were taken from freeze-dried, crushed sediment from core LZ1029-7 housed at the University of Massachusetts Amherst. Each vial represents a $2 \mathrm{~cm}$ section of the core. Sample depths can be found in Table 1. Six samples were taken from the earlier PG1351 core at greater depths than LZ1029-7 to extend the longer record as well as comparison to trends within LZ1029-7. Automated logging of magnetic susceptibility was measured at the University of Massachusetts Amherst on the whole core. A selection of 33 samples from LZ1029-7 was taken to the Institute of Rock Magnetism (IRM) at the University of Minnesota in Minneapolis for detailed magnetic measurements. Magnetic susceptibility and hysteresis properties were measured on all samples brought to the IRM, and nine samples were tested using the Magnetic Properties Measurement System (MPMS) for various low temperature magnetic properties.

\subsubsection{Magnetic susceptibility}

Magnetic susceptibility was measured over the entire split core of LZ1029-7 at the University of Massachusetts Amherst using an automated logging system equipped with a Barrington Magnetic Susceptibility 2E/1 spot reading sensor at $1-\mathrm{mm}$ increments. This measurement provided a continuous magnetic susceptibility measurement by volume $(\kappa)$. Magnetic susceptibility measurements on the 31 discrete samples were made with a Geofyzika KLY-2 KappaBridge AC Susceptibility Bridge at the Institute of Rock Magnetism (IRM) at the University of Minnesota. Initial, or low field, 

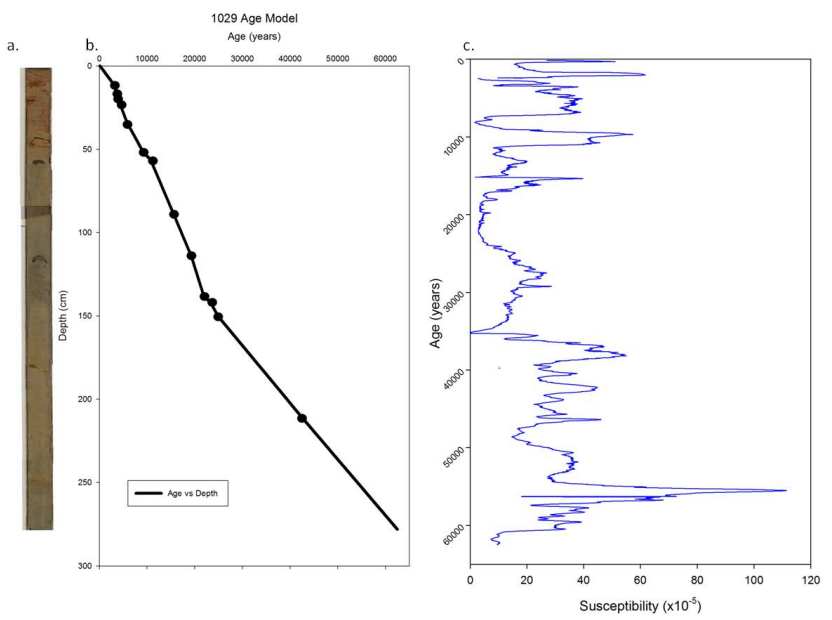

Fig. 3. Depth-age model developed for 3-m core LZ1029-7 based on linear interpolation of ages between tie points between cores LZ1029-5/8/9 and PG1351. (a) High resolution scanned image of core LZ1029-7 prior to sampling. (b) Depth-age model for core LZ1029-7. Correlation between cores was based on sedimentology and stratigraphic markers (e.g. turbidites, ash layer) and fluctuations in the TOC and bulk ${ }^{13} \mathrm{C}_{\text {org }}$ data. Tie points are marked by black circles. (c) Magnetic susceptibility $(\kappa)$ of LZ1029-7.

susceptibility is herein referred to as $\chi$ or $\chi_{\mathrm{lf}}$, and is mass normalized. Additionally, high field susceptibility $\left(\chi_{\mathrm{hf}}\right)-$ also mass normalized - was measured at a field ten times that of the low field susceptibility $\left(\chi_{\mathrm{lf}}\right)$.

\subsubsection{Hysteresis}

Hysteresis loops were measured from the twenty-five LZ1029-7 and six PG1351 samples using a Princeton Measurements Vibrating Sample Magnetometer at the Institute of Rock Magnetism at the University of Minnesota. Peak magnetizing fields of $1 \mathrm{~T}$ were used, with continuous measurements of magnetization and coercivity.

\subsubsection{Low temperature magnetic properties}

Low temperature remanence measurements were made on nine samples, five from LZ1029-7 and four from PG1351, using a Quantum Designs MPMS2 Cryogenic Susceptometer at the Institute of Rock Magnetism. All samples underwent room temperature saturating isothermal remanent magnetization (RT-SIRM) of $2.5 \mathrm{~T}$. The remanence was measured as temperature was reduced in $5 \mathrm{~K}$ increments to $10 \mathrm{~K}$ and then back to room temperature. In addition to RT-SIRM, two other measurements were made on three of the samples. Samples were also cooled in either a $2.5 \mathrm{~T}$ field (FC) or no field (ZFC). Remanence was then measured in increments of $5 \mathrm{~K}$ upon warming to room temperature after a $2.5 \mathrm{~T}$ field was applied at $10 \mathrm{~K}$.
Table 1. Samples taken from LZ1029-7 and PG1351 for discrete susceptibility and other rock magnetic property measurements.

\begin{tabular}{lrrr}
\hline Sample \# & Depth (cm) & Approx. Age $(\mathrm{yr})$ & Susceptibility $(\chi) \times 10^{-5}$ \\
\hline LZ1029-7-5 & 9 & 2459 & 0.1357 \\
LZ1029-7-12 & 23 & 4360 & 0.1418 \\
LZ1029-7-14 & 27 & 4889 & 0.1509 \\
LZ1029-7-24 & 47 & 8299 & 0.1529 \\
LZ1029-7-25 & 49 & 8682 & 0.179 \\
LZ1029-7-26 & 51 & 9064 & 0.1621 \\
LZ1029-7-27 & 53 & 9617 & 0.1313 \\
LZ1029-7-28 & 55 & 10341 & 0.08729 \\
LZ1029-7-32 & 63 & 11739 & 0.05546 \\
LZ1029-7-43 & 85 & 14997 & 0.09155 \\
LZ1029-7-49 & 97 & 16769 & 0.06683 \\
LZ1029-7-56 & 111 & 18834 & 0.05695 \\
LZ1029-7-60 & 119 & 19821 & 0.0261 \\
LZ1029-7-64 & 127 & 20692 & 0.02787 \\
LZ1029-7-65 & 129 & 20910 & 0.02821 \\
LZ1029-7-68 & 135 & 21564 & 0.02001 \\
LZ1029-7-69 & 137 & 21782 & 0.0252 \\
LZ1029-7-70 & 139 & 22252 & 0.02063 \\
LZ1029-7-71 & 141 & 22973 & 0.02049 \\
LZ1029-7-73 & 145 & 23905 & 0.02178 \\
LZ1029-7-81 & 161 & 28044 & 0.03825 \\
LZ1029-7-91 & 181 & 33836 & 0.09028 \\
LZ1029-7-94 & 187 & 35573 & 0.07539 \\
LZ1029-7-96 & 191 & 36732 & 0.05825 \\
LZ1029-7-98 & 195 & 37890 & 0.07096 \\
LZ1029-7-103 & 205 & 40786 & 0.05852 \\
LZ1029-7-108 & 215 & 43722 & 0.09202 \\
LZ1029-7-109 & 217 & 44318 & 0.08688 \\
LZ1029-7-111 & 221 & 45509 & 0.08644 \\
LZ1029-7-114 & 227 & 47295 & 0.1134 \\
LZ1029-7-115 & 229 & 48742 & 0.1097 \\
LZ1029-7-119 & 237 & 57939 & 0.1013 \\
LZ1029-7-122 & 243 & 63338 & 0.01724 \\
LZ1351-391 & 392 & 95790 & 0.03065 \\
LZ1351-477 & 478 & 111349 & \\
LZ1351-481 & 482 & 111651 & 0.01292 \\
LZ1351-585 & 586 & 137004 & \\
LZ1351-609 & 610 & 149993 & \\
LZ1351-1118 & 1119 & 279770 & \\
\hline & & & \\
\hline
\end{tabular}

\subsection{Organic geochemistry}

Preliminary analysis of this core was undertaken to guide further sampling for organic geochemical analyses. Representative samples were also collected to identify target compounds for use in compound specific isotopic analysis of Lake El'gygytgyn sediments (both $\delta^{13} \mathrm{C}$ and $\delta \mathrm{D}$ ). These samples were also used to streamline the analytical method to be used on smaller samples collected from a longer sediment core, LZ1024. Sediment samples from core LZ1029-7 were freeze-dried, crushed and stored in combusted glassware $(2 \mathrm{~cm}$ sampling resolution; 139 samples total). Each sample was sub-sampled for both total organic carbon content (\%TOC) and bulk $\delta^{13} \mathrm{C}_{\text {org }}$ analysis.

\subsubsection{TOC analysis}

After freeze-drying and homogenization in an agate mortar, sediment samples were packed in tin capsules and acidified ( $1 \mathrm{~N} \mathrm{H}_{2} \mathrm{SO}_{3}$, evaporated to dryness at $55^{\circ} \mathrm{C}$ for $12 \mathrm{~h}$ ) prior to 
analysis to remove carbonates. Total organic carbon concentrations were determined using a Costech ECS140 Elemental Analyzer (Costech, Valencia, CA). Total organic carbon content was calculated from the integrated response of the sample compared to a calibration curve derived from standard samples of known $\mathrm{C}$ and $\mathrm{N}$ content (acetanilide: $71.09 \% \mathrm{C}$, $10.38 \% \mathrm{~N}$ ). The precision, calculated by replicate analysis of the internal standard was $0.4 \%$ for TOC.

\subsubsection{Bulk $\delta^{13} \mathrm{C}_{\text {org }}$ analysis}

Samples for bulk $\delta^{13} \mathrm{C}_{\text {org }}$ analysis were also acidified $(1 \mathrm{~N}$ $\mathrm{H}_{2} \mathrm{SO}_{3}$, evaporated to dryness at $55^{\circ} \mathrm{C}$ for $12 \mathrm{~h}$ ) prior to analysis to remove carbonates. Bulk $\delta^{13} \mathrm{C}_{\text {org }}$ values were determined by continuous flow isotope ratio mass spectrometry using a Costech elemental combustion system (ECS140 EA) interfaced to a Thermo Delta $\mathrm{V}$ isotope-ratio mass spectrometer (EA-irms). Analyses were run in triplicate and are reported relative to the Vienna PDB (VPDB) standard in per mil (\%o) notation. More detailed description of $\delta^{13} \mathrm{C}$ methods and results can be found in Holland et al. (2013).

\section{Results}

The automated magnetic susceptibility logging of core LZ1029-7 provided an initial look at the range of the susceptibility to compare to the earlier core PG1351 (Fig. 4). The range in volume susceptibility $(\kappa)$ is $2.0 \times 10^{-6}$ to $1.11 \times$ $10^{-3}$ SI. Magnetic susceptibility shows a wide variability in range, at least 2 orders of magnitude, as was shown in the previously measured cores, proving reliability between cores and providing further evidence that PG1351 and LZ1029-7 can plausibly be compared.

Thirty-three discrete samples from various points in the core LZ1029-7 were measured for magnetic susceptibility $(\chi)$ at the IRM (Table 1, Fig. 5). Overall the susceptibility shows a similar trend as compared to the down core logging of susceptibility which is to be expected due to the large difference in measurement intervals. Continuous susceptibility was measured at every $1 \mathrm{~mm}$, whereas the discrete samples were taken from mixed $2 \mathrm{~cm}$ intervals. Also, the continuous susceptibility was volume normalized $(\kappa)$ whereas the discrete samples were mass normalized $(\chi)$. The range in susceptibility $(\chi)$ for the discrete samples is $1.29 \times 10^{-7}$ to $2.49 \times 10^{-6} \mathrm{~m}^{3} \mathrm{~kg}^{-1}$.

Hysteresis properties are shown in a Day plot (Day et al., 1977) (Fig. 6) using the parameters modified in Dunlop (2002a, b). The shapes of most of the hysteresis loops indicate the major magnetic mineral is most likely magnetite or another soft magnetic mineral (Fig. 7). For samples from LZ1029-7, magnetic remanence (Mr) versus saturation magnetization (Ms) range from 0.10 to 0.19 . PG1351 samples have a similar range (Nowaczyk et al., 2002), with the exception of a few samples in the multi-domain (MD) range

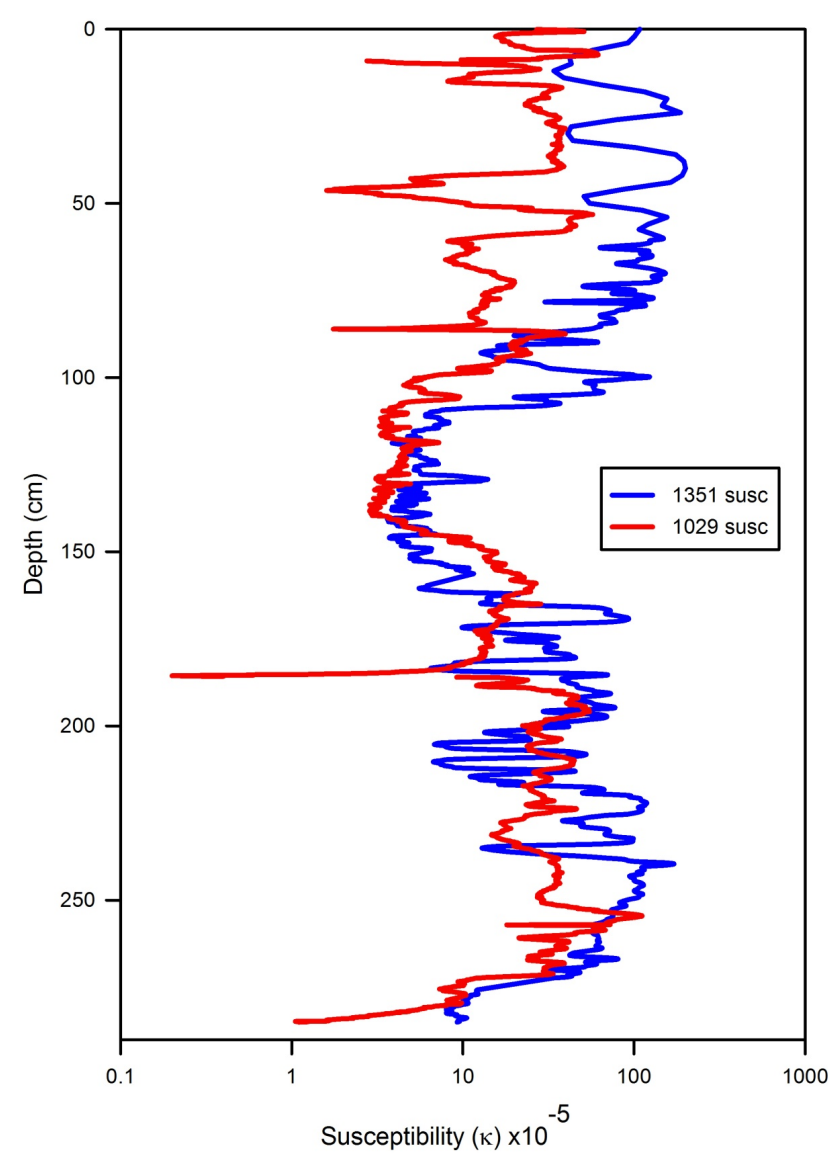

Fig. 4. Comparison of susceptibility $(\kappa)$ between PG1351 (Nowaczyk, et al., 2002, 2007) and LZ1029.

(Fig. 6). Corresponding coercivity of remanence to coercive force measurements $(\mathrm{Hcr} / \mathrm{Hc})$ in LZ1029-7 vary from 2.46 to 3.31. These data reveal that the samples fall entirely within the pseudo-single domain (PSD) field, indicating magnetite grains $0.1-20 \mu \mathrm{m}$ in size. Samples studied here from PG1351 also plot within the PSD field, but show a wider range of values. The PSD grain size is consistent with detrital input of magnetite grains from the crater surrounding Lake El'gygytgyn.

Low temperature magnetic properties data indicate the presence of magnetite, as seen from the strong Verwey transition present at $120 \mathrm{~K}$ (Fig. 8). There is some indication of titanomagnetite in several samples where the Verwey transition occurs over the range between $110 \mathrm{~K}$ and $120 \mathrm{~K}$. This is consistent with the minerals found in the surrounding lithologies at the lake that would be the main sources of magnetic minerals.

Anomalous changes in the magnetic properties are observed at temperatures between $10 \mathrm{~K}$ and $40 \mathrm{~K}$ during MPMS runs. Small changes are observed in several samples at $12 \mathrm{~K}$ (Fig. 8f), indicative of vivianite (Frederichs et al., 2003). Vivianite can be visibly observed within the cores taken from 


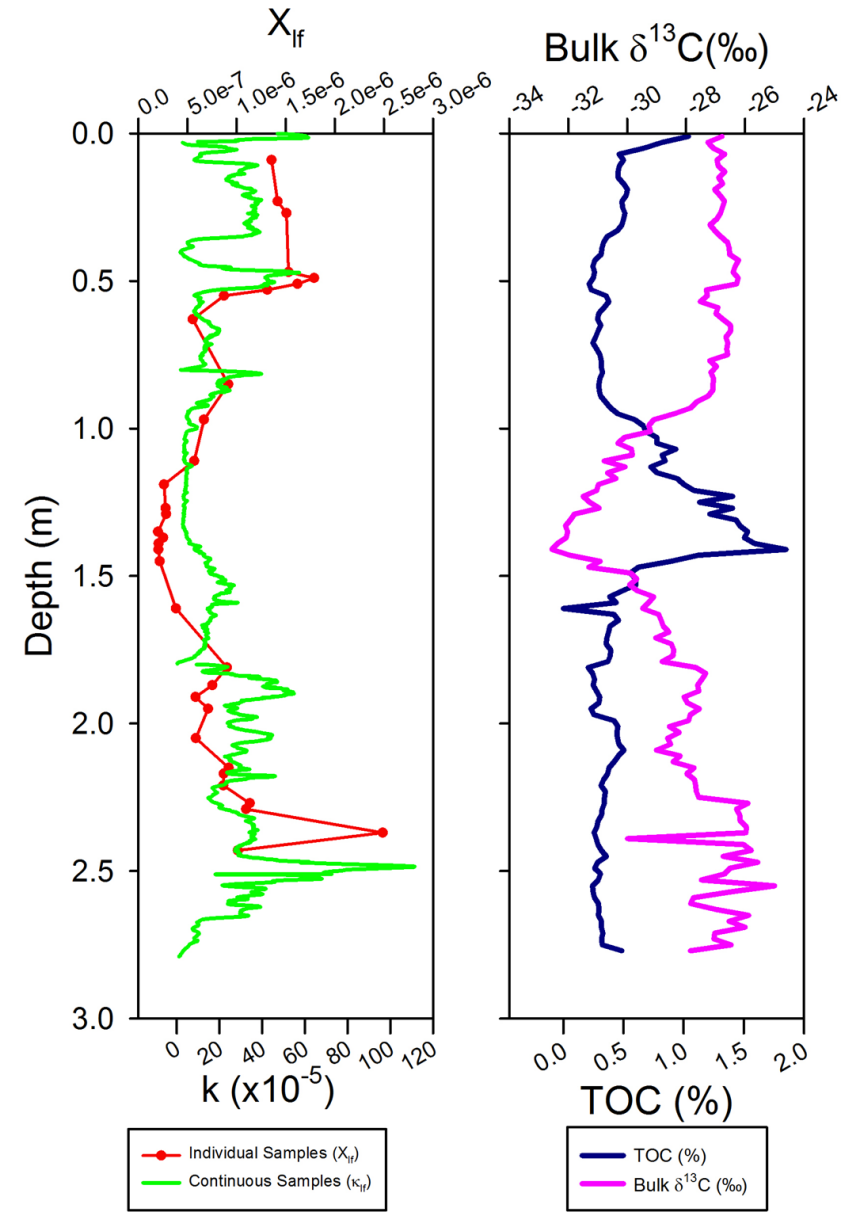

Fig. 5. Comparison of magnetic susceptibility $\left(\chi_{\text {If }}\right.$ and $\kappa$, red and green curves, respectively), bulk $\delta^{13} \mathrm{C}_{\text {org }}$ (pink), TOC (purple).

Lake El'gygytgyn (Minyuk et al., 2007), and for that reason it is plausible to find small amounts of vivianite in various areas of the core. Changes in the magnetic properties at slightly higher temperatures $(\sim 25 \mathrm{~K})$ as seen in Fig. 8 b, $\mathrm{c}$, and e point to the presence of pyrrhotite, siderite and/or rhodochrosite $-\mathrm{Fe}_{(1-x)} \mathrm{S}, \mathrm{FeCO}_{3}$ and $\mathrm{MnCO}_{3}$, respectively. These minerals are paramagnetic at room temperature but become magnetic at low temperatures.

Total organic carbon (TOC) concentrations are very low, ranging from $0.2 \%$ to $1.9 \%$ (Fig. 5). The range of TOC values is slightly smaller in core LZ1029-7 than observed in core PG1351 (ranges from $0.1 \%$ to $2.5 \%$; Melles et al., 2007); however, the trends are very similar. Repeated movement of the redox boundary within the sediments and extending into the water column has been linked with decomposition of organic matter (Lehmann et al., 2002; Melles et al., 2007). Fluctuations in TOC are anti-correlated with transitions in bulk $\delta^{13} \mathrm{C}_{\text {org }}$ (Fig. 3). The lower correlation between TOC and bulk $\delta^{13} \mathrm{C}_{\mathrm{org}}$ in the bottom $\sim 50 \mathrm{~cm}$ of core LZ1029-7 may be due to coring disturbance weakly visible in the bottommost section of this core.

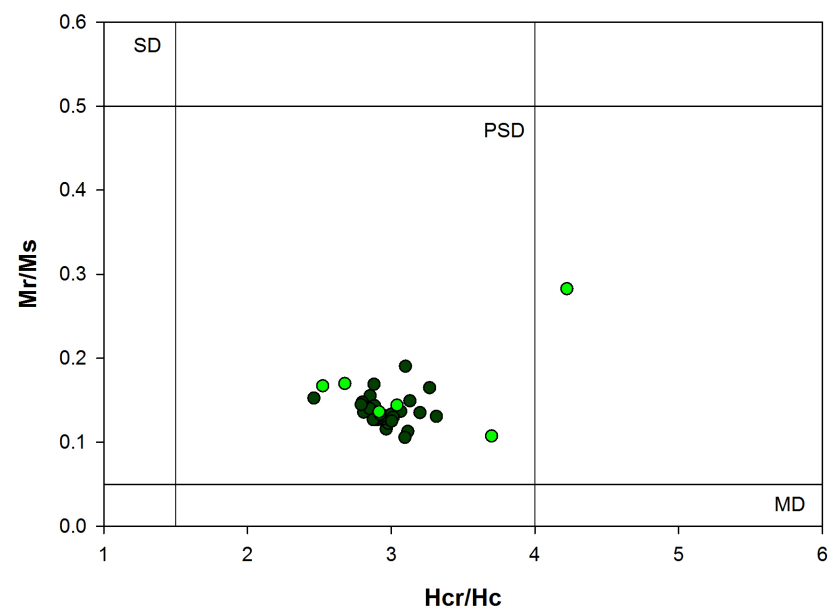

Fig. 6. Day plot of LZ1029 (dark green circles) and PG1351 (light green circles) all plotting within the PSD range.

\section{Discussion}

Cores PG1351 and LZ1024 provide information over several glacial/interglacial cycles. Although LZ1029-7 is significantly shorter, this core provides an opportunity for investigation of the most recent glacial/interglacial cycle at high resolution. The highest values of TOC, lowest values of bulk $\delta^{13} \mathrm{C}_{\mathrm{org}}$, and magnetic susceptibility highlight the Last Glacial Maximum (LGM), occurring about $20 \mathrm{ka}$, at about $1.45 \mathrm{~m}$ sediment depth. Both the Holocene (most recent interglacial) and Marine Isotope Stage 3 (MIS3) are well represented above and below the LGM in the core, respectively, marking transitions into and out of the glacial period from interglacials.

Differences can be seen between $\kappa$ and $\chi$ susceptibility measurements (Fig. 5), nevertheless major trends are still present. This is to be expected since the measurement intervals are so drastically different, and because most of the discrete samples taken were preferentially taken from areas of lower susceptibility to better understand lake processes during glacial periods (Table 1). The consistency in the ranges of magnetic susceptibility between PG1351 and LZ1029-7 provides the important insight that the wide range of susceptibilities is consistent between the two cores, and possibly pervasive throughout the lake, at least in the upper part of the sediment record. The areas of high susceptibility can be interpreted as a result of the high magnetic mineral content of the surrounding rocks being transported into the lake during warmer interglacials, consistent with previous investigations of grain size and sediment transport (Asikainen et al., 2006). Areas of low susceptibility indicate a lessening effect in the erosion of the sediment into the lake and correlate to the glacial periods of the region. Yet, the orders of magnitude difference in susceptibility between glacial and interglacial periods does not seem to be resolved solely by fluctuations in sediment transport. 


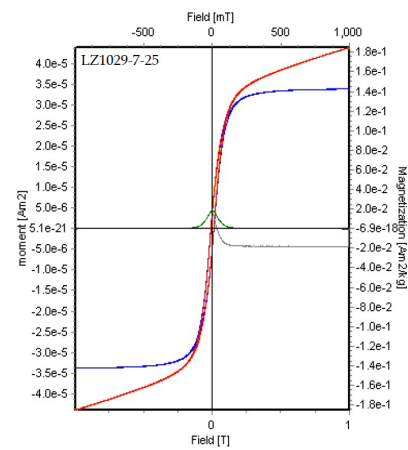

a)

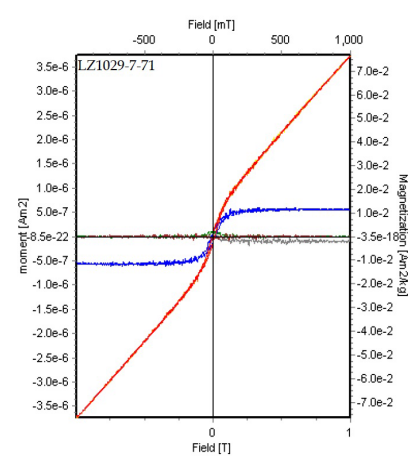

e)

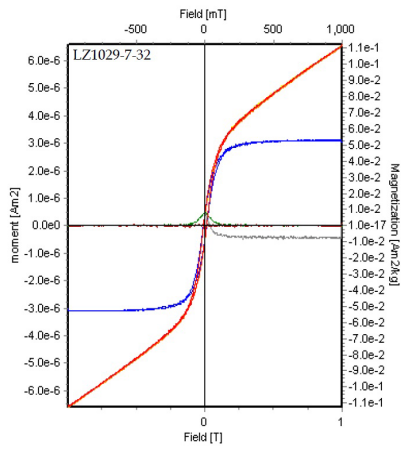

b)

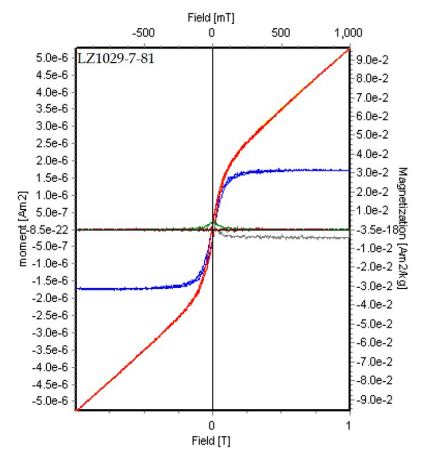

f)

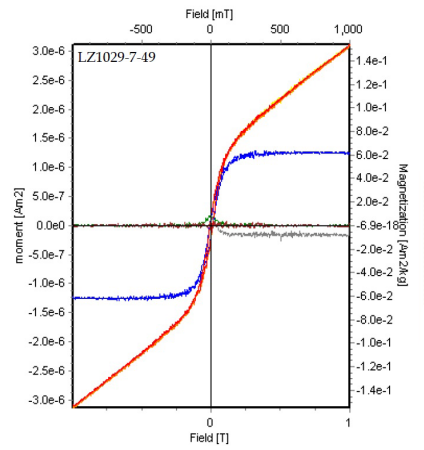

c)

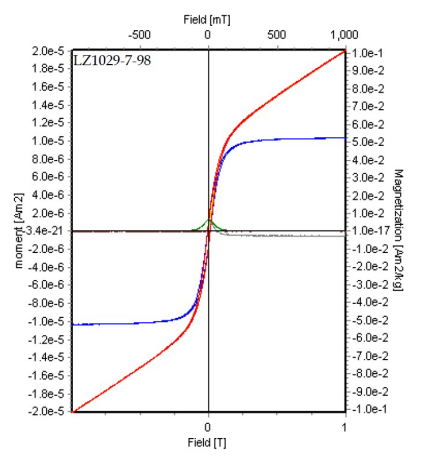

g)

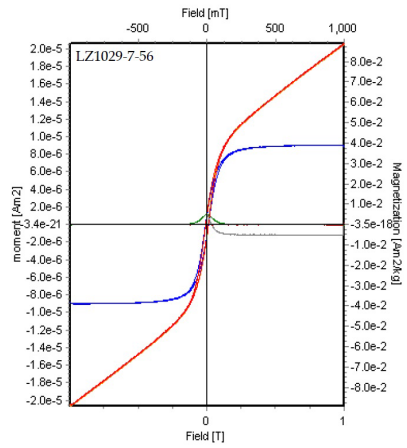

d)

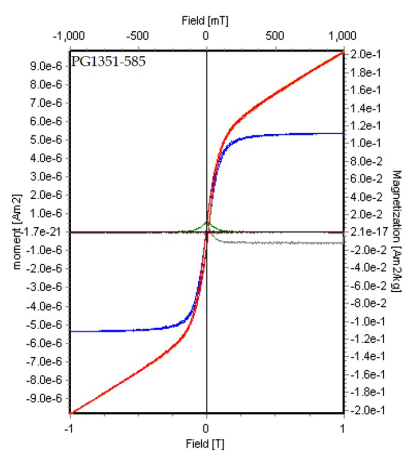

h)

Fig. 7. Selected examples of hysteresis loops from high susceptibility areas (a, b, $\mathbf{g}, \mathbf{h})$, transitional (c, $\mathbf{d}, \mathbf{f})$ and low susceptibility areas (e) in LZ1029. Loops have been corrected for paramagnetic contribution.

Perennial ice cover and lake stratification that would have resulted in bottom water anoxia, reducing degradation and increasing preservation of organic material, also show the highest values of TOC during glacial periods (Melles et al., 2007). During these cold, dry climate modes (Melles et al., 2007), persistent ice cover excluded wind generated mixing as well as seasonal density-driven overturning by warming surface waters. Although extremely limited terrestrial input at these times would be expected, aquatic productivity likely remained relatively high, which may also contribute to higher TOC values. Investigation of the molecular composition of this TOC confirms a higher ratio of aquatic to terrestrial input during glacial periods (Wilkie, 2012; Holland et al., 2013). TOC values are low during warmer, interglacial periods possibly due to greater organic matter degradation within a fully mixed, oxic water column, likely extending to the sediment water interface. Reactive organic matter degrades at similar rates under oxic and anoxic conditions (Kristensen and Holmer, 2001); however, the proportion of organic matter resistant to degradation is much lower under anoxic conditions (Borrel et al., 2011). Notably, only minor fluctuations in TOC values are observed from $\sim 60 \mathrm{ka}$ to $75 \mathrm{ka}$, in contrast with a distinctly higher trend in core PG1351. This may be due to lower preservation of LZ1029-7 as laminations noted within this interval in sister cores 1029-5/8/9/ and PG1351 were absent. Large excursions in bulk ${ }^{13} \mathrm{C}_{\text {org }}$ during glacial intervals along with higher TOC values suggest migration of the redox boundary into the water column and enhanced preservation of organic matter coupled with possibly greater bacterial methanogenesis. Bacterial methane oxidation would produce isotopically light carbon within the lake, eventually resulting in overall reduction of bulk ${ }^{13} \mathrm{C}_{\mathrm{org}}$ values. Investigation of compound-specific $\delta^{13} \mathrm{C}$ signatures will help to better identify and deconvolute the source(s) of the ${ }^{13} \mathrm{C}_{\text {org }}$ depletion (Holland et al., 2013; Wilkie et al., 2013).

Total organic carbon (TOC) measurements were performed in LZ1029-7, although total carbon (TC) was not measured. At the time, it was believed that carbonate was not present in Lake El'gygytgyn sediments and therefore the major contribution to carbon within the lake was due to aquatic flora and fauna and the influx of terrestrial organic matter. During glacial periods, it is theorized the lack of oxygen in the bottom waters of the lake supply an environment where the organic material would be preserved rather than oxidized as it would be during interglacials. Magnetic susceptibility is widely used as an indicator of terrestrial input into the lake, 
a)

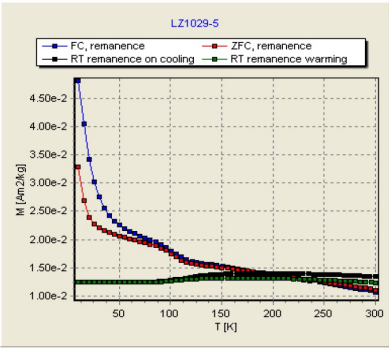

b)

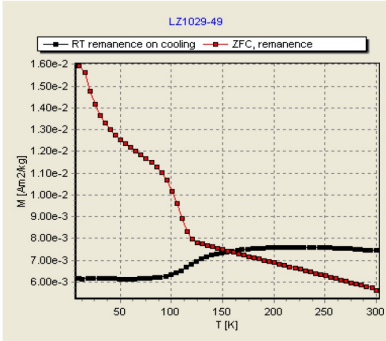

c)

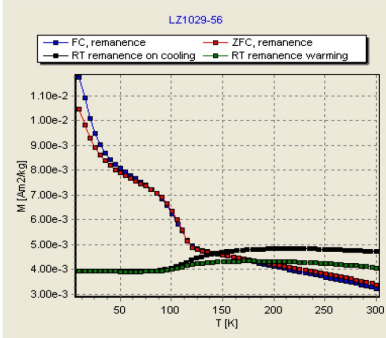

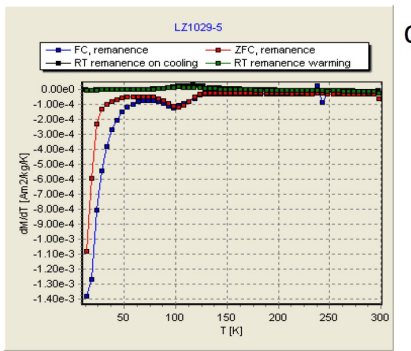

d)

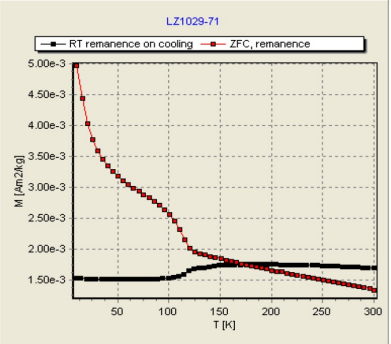

e)
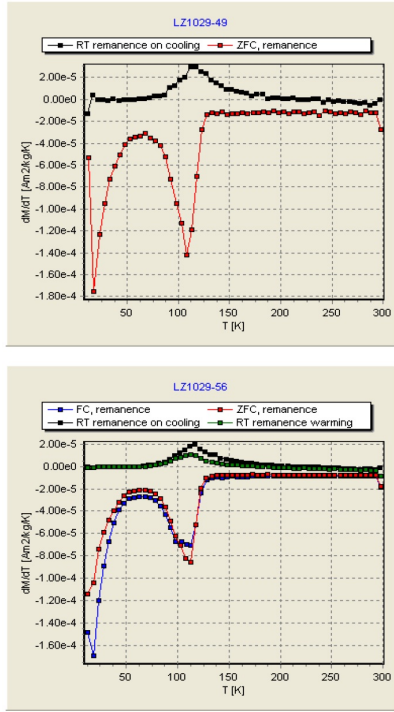

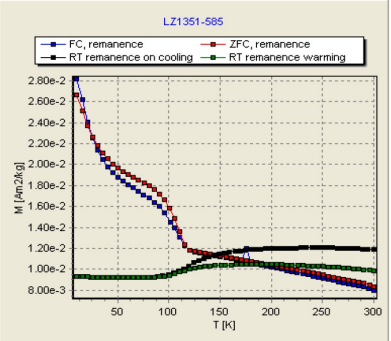

f)

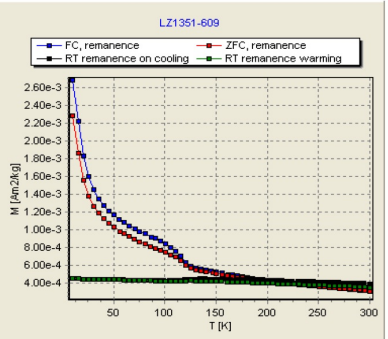

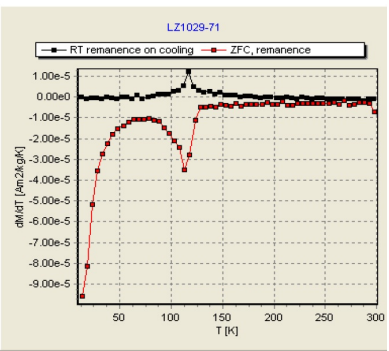
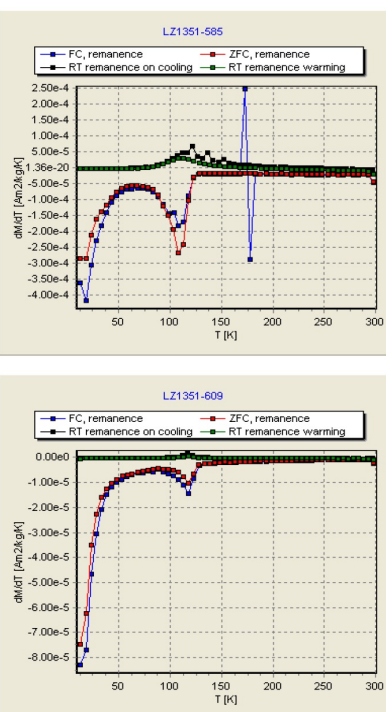

Fig. 8. A selection of MPMS graphs from LZ1029 and PG1351. Left-hand columns show original graphs from MPMS measurements. Righthand columns show the derivatives of the left graphs to better indicate changes in slope between 10 and $35 \mathrm{~K}$, indicating the presence of room-temperature paramagnetic minerals vivianite and siderite (or rhodochrosite), which become magnetic at about 12 and $32 \mathrm{~K}$, respectively. Samples from LZ1029 were from depths of (a) $5 \mathrm{~cm}$, (b) $49 \mathrm{~cm}$, (c) $56 \mathrm{~cm}$, and (d) $71 \mathrm{~cm}$. Samples from PG1351 were from depths of (e) $585 \mathrm{~cm}$ and (f) $609 \mathrm{~cm}$.

and therefore in this area should be higher during warm and wet climates (i.e. interglacials), and lower during periods of ice cover and cold, dry climates (i.e. glacial) and therefore be anticorrelated with TOC. When the continuous magnetic susceptibility is compared to the TOC (Fig. 5), there is agreement in many parts of the core. Most notably, what is considered to be the Last Glacial Maximum in the TOC record (high peak at about $1.5 \mathrm{~m}$ in Fig. 5) does correlate well with the low susceptibility at about the same depth. Discrepancies between TOC and MS may be explained by the presence of large amounts of inorganic carbon, but given that TC was not measured, it cannot be proven explicitly. It would be assumed that such a large amount of inorganic carbon would be in the form of carbonate, yet this was not found in the early geochemical analyses of the lake sediments (Melles et al., 2007; Minyuk et al., 2007).

MPMS data consistently shows the presence of magnetite with a strong Verwey transition at about $120 \mathrm{~K}$ (Fig. 8), and there is no indication of the presence of hematite with a Morin transition at $260 \mathrm{~K}$. Hematite would not be expected, given the theory that severely anoxic bottom waters associated with glacial periods would dissolve magnetite and therefore an oxidizing environment in which to create hematite would be lacking. There may be mixing of magnetic minerals that influence the Verwey transition to a slightly lower temperature (such as magnetite and titanomagnetite) (Fig. 8a, d, e). Hematite does not appear to be a major influence if it is even present at all.

As observed in several samples there is anomalous behavior between $20 \mathrm{~K}$ and $30 \mathrm{~K}$ (Fig. 8b, c and e). Pyrrhotite, rhodochrosite, and siderite all have Néel temperatures within this range: both siderite and rhodochrosite are paramagnetic above their Néel temperatures, where siderite becomes antiferromagnetic and rhodochrosite becomes canted antiferromagnetic (Frederichs et al., 2003). At this temperature the structure of pyrrhotite changes from monoclinic to triclinic (Wolfers et al., 2011). It is unlikely that pyrrhotite should be found in Lake El'gygytgyn in measurable amounts since it is a sulfur-limited system. Lake chemistry measurements suggest a deficiency in sulfur (Melles et al., 2007), and therefore it is unlikely pyrrhotite would be present. Siderite and rhodochrosite are better candidates for minerals present in 
the lake sediments and coincide with the observed Néel temperatures and may explain the apparent "missing source" of inorganic carbon. In addition, iron and manganese have been measured in lake water geochemistry (Melles et al., 2007), yet iron is most certainly more abundant than manganese. However, using just low-temperature magnetic properties, it is not possible in this study to determine if the Néel temperature observed is related to the presence of siderite or rhodochrosite, or both. The presence of one or both of these minerals, which were originally not thought to be present in the lake since they are carbonates, can provide useful information as to climatic change and lake biogeochemical cycling, since both require anoxic waters for their genesis. Their presence also indicates that carbonate is present in Lake El'gygytgyn and therefore TIC is a necessary measurement to make in order to attain a clear picture of the carbon within the lake.

Some samples also exhibited a change in slope at approximately $15 \mathrm{~K}$ (Fig. 8d and f), which most likely indicates the presences of vivianite. Vivianite has been observed in significant proportions (Minyuk et al., 2007) and therefore its presence in low temperature magnetic measurements is more than feasible. However, unlike the widespread vivianite Minyuk et al. (2012) observes, low temperature measurements indicating vivianite are not consistent through all samples measured (Fig. 8a). This may be due to the greater proportions of other magnetic minerals present in the samples tested, including magnetite, titanomagnetite, and possibly even siderite or rhodochrosite.

The presence of the low-temperature magnetic minerals siderite, rhodochrosite and vivianite are indicative of anoxic bottom waters (Frederichs et al., 2003), and therefore support the hypothesis that magnetite was dissolved in Lake El'gygytgyn during glacial intervals. Rhodochrosite forms in anoxic waters that may or may not contain significant sulfur. Siderite, alternatively, cannot form in a sulfidic environment, yet still forms in an anoxic environment. Since Lake El'gygytgyn is a fresh water lake, and water chemistry does not indicate a substantial amount of sulfur (Melles et al., 2007), it would be possible for siderite to form, as well as rhodochrosite. Vivianite forms in severely anoxic waters, which may provide evidence for differing depositional environments within the lake.

However, it is still not clear what quantity of magnetite is dissolved, if all of it forms siderite or vivianite or other minerals as of yet unidentified, at what point these minerals are precipitated, and why the magnetic susceptibility is several orders of magnitude different between glacial and interglacials. It should be noted, however, that pollen (Lozhkin et al., 2006) and biomarker investigations (Wilkie et al., 2013) have documented continued input of pollen and terrestrial leaf wax lipids during glacial intervals and throughout glacial/interglacial cycles. Nowaczyk et al. (2002) and Melles et al. (2007) have postulated that glacial intervals would provide cold enough temperatures year round for perennial ice cover over Lake El'gygytgyn. However, the presence of these terrestrial sources have led to the theory that during full glacial summer months, moat formation around the perimeter of perennial ice cover could provide a mechanism to allow terrestrial signals into the lake (Wilkie et al., 2013). If this theory is valid, then there should be some small but significant input of sediment into the lake that would provide magnetic particles and therefore a more significant magnetic susceptibility measurement than is seen during glacial periods. Because a more significant susceptibility measurement is not found during glacial periods and the presence of minerals that form in anoxic environments (siderite, rhodochrosite, vivianite) can be found throughout the core, magnetite dissolution due to lake stratification is a highly probable theory to explain some of the magnetic measurements.

Susceptibility may provide an effective proxy for some climatic models, but based on the work in this study and of that done previously there may be other influences that need to be addressed in order to create a reasonable climate proxy. The most glaring issue with susceptibility is the large range measured between glacial and interglacials. Dissolution is a very plausible theory as to why there is such a wide range; however, the iron freed from dissolution of magnetite must be utilized somewhere else in the lake, be it as free iron in the sediment, the formation of secondary minerals, or the utilization of iron by aquatic life. There is not enough evidence that the amount of siderite or vivianite observed in LZ1029-7 could utilize the amount of free iron from magnetite dissolution.

\section{Conclusions}

As an initial investigation of rock magnetism, this study justifies the further investigation of magnetic properties and how, as climate proxies, they relate to environmental and climatic changes. Susceptibility and TOC measurements on LZ10297 further validate the initial observations on PG1351 of the large oscillations between glacial and interglacial periods. For glacial periods, perennial ice cover with or without moat formation during glacial summer months would prohibit complete mixing within the lake and hence it would become stratified, creating an anoxic bottom water layer. This, therefore, would provide the correct environment for magnetite to dissolve, and thus continues to prove to be a valid theory and is further corroborated by the magnetic minerals found at low temperatures.

Irregularities in MPMS measurements at about $10 \mathrm{~K}$ and $32 \mathrm{~K}$ indicate the occurrence of minor low-temperature magnetic minerals such as vivianite and siderite (respectively) the former having been observed in the core by visual inspection and other methods - and possibly rhodochrosite. These minerals can help to identify the bottom water setting (suboxic to severely anoxic) at various times in the past 
which then can be utilized to reconstruct climate over time that would produce such environments. The presence of these minerals further supports the theory of magnetite dissolution in Lake El'gygytgyn; however, its pervasiveness over time - and extensiveness throughout the lake - is still not well determined. Additional detailed comparison between carbon measurements (both organic and inorganic) and susceptibility will need to be more thorough to fully address and understand lake biogeochemical cycling at Lake El'gygytgyn, as will the comparison between magnetic susceptibility and $\mathrm{TiO}_{2}$. More work is required to fully understand the magnetic, geochemical, and biogenic consequences of the dissolution of magnetite, and through that understanding, hopefully better clarify the connection between terrestrial input, organic matter preservation, and magnetic properties within Lake El'gygytgyn.

Acknowledgements. Funding for this research was provided by the International Continental Scientific Drilling Program (ICDP), the US National Science Foundation (NSF), the German Federal Ministry of Education and Research (BMBF), Alfred Wegener Institute (AWI) and Geo Forschungs Zentrum Potsdam (GFZ), the Russian Academy of Sciences Far East Branch (RAS FEB), the Russian Foundation for Basic Research (RFBR), and the Austrian Federal Ministry of Science and Research (BMWF). The Russian GLAD 800 drilling system was developed and operated by DOSECC Inc., the downhole logging was performed by the ICDP-OSG, and LacCore, at the University of Minnesota, handled core curation. The authors would like to thank Richard Reynolds for his contributions to this paper, and the two reviewers, A. Hirt and A. Tudryn, for their constructive remarks.

Edited by: P. Minyuk

\section{References}

Asikainen, C. A., Francus, P., and Brigham-Grette, J.: Sedimentology, clay mineralogy and grain-size as indicators of $65 \mathrm{ka}$ of climate change from El'gygytgyn Crater Lake, Northeastern Siberia, J. Paleolimnol., 37, 105-122, doi:10.1007/s10933-0069026-5, 2006

Anderson, P. M., Lozhkin, A. V., and Brubaker, L. B.: Implications of a 24.000-Yr Palynological Record for a Younger Dryas Cooling and for Boreal Forest Development in Northeastern Siberia, Quaternary Res., 57, 325-333, doi:10.1006/qres.2002.2321, 2002.

Begét, J. E.: Tephrochronology and paleoclimatology of the Last Interglacial-Glacial cycle recorded in Alaskan loess deposits, Quaternary Int., 34-36, 121-126, doi:10.1016/10406182(95)00076-3, 1996.

Belyi, V. F. and Raikevich, M. I.: The El'gygytgyn Hollow (geology and morphology, impactites, problems of research and protection of an inanimate nature), NEISRI FEB Russian Acad. Sci., Magadan, 1994 (in Russian).

Belyi, V. F., Belaya, B. V., and Raikevich, M. I.: Pliocene deposits of upstream of the Enmyvaam River and the age of impactogenesis in the El'gygytgyn Lake Hollow, NEISRI FEB Russian Acad. Sci., Magadan, 1994 (in Russian).

Borrel, G., Jézéquel, D., Biderre-Petit, C., Morel-Desrosiers, N., Morel, J., Peyret, P., Fonty, G., and Lehours, A.: Production and consumption of methane in freshwater lake ecosystems, Res. Microbiol., 162, 832-847, doi:10.1016/j.resmic.2011.06.004, 2011.

Brigham-Grette, J., Melles, M., Minyuk, P., and Scientific Party: Overview and significance of a $250 \mathrm{ka}$ paleoclimate record from El'gygytgyn Crater Lake, NE Russia, J. Paleolimnol., 37, 1-16, doi:10.1007/s10933-006-9017-6, 2007.

Chlachula, J., Evans, M. E., and Rutter, N. W.: A magnetic investigation of a Late Quaternary loess/palaeosol record in Siberia, Geophys. J. Int., 132, 128-132, doi:10.1046/j.1365246x.1998.00399.x, 1998

Day, R., Fuller, M., and Schmidt, V.: Hysteresis Properties of Titanomagnetites - Grain-Size and Compositional Dependence, Phys. Earth Planet. Int., 13, 260-267, doi:10.1016/00319201(77)90108-X, 1977.

Demory, F., Nowaczyk, N. R., Witt, A., and Oberhänsli, H.: High-resolution magnetostratigraphy of late quaternary sediments from Lake Baikal, Siberia: timing of intracontinental paleoclimatic responses, Global Planet. Change, 46, 167-186, doi:10.1016/j.gloplacha.2004.09.016, 2005.

Dunlop, D. J.: Theory and application of the Day plot (Mrs/Ms versus $\mathrm{Hcr} / \mathrm{Hc}$ ) 1. Theoretical curves and tests using titanomagnetite data, J. Geophys. Res., 107, 2056, doi:10.1029/2001JB000486, 2002a.

Dunlop, D. J.: Theory and application of the Day plot (Mrs/Ms versus $\mathrm{Hcr} / \mathrm{Hc}$ ) 2. Application to data for rocks, sediments, and soils, J. Geophys. Res., 107, 2057, doi:10.1029/2001JB000487, 2002b.

Evans, M. E. and Heller. F.: Magnetism of loess/palaeosol sequences: recent developments, Earth-Sci. Rev., 54, 129-144, 2001.

Evans, M. E. and Heller, F.: Environmental Magnetism: Principles and Applications of Environmagnetics, Elsevier Science, USA, 2003.

Evans, M. E. and Rutter, N. W.: A magnetic investigation of a late Quaternary loess/palaeosol record in Siberia, Geophys. J. Int., 132, 128-132, 1998.

Federov, G., Bolshijanov, D. J., and Schwamborn, G.: Hydroand sedimentological-balance research from Lake Elgygytgyn, Chukotka, in: The System of the Laptev Sea and Adjacent Arctic Seas Current Status and History of Development, edited by: Kassens, K., Lisitzin, A. P., Thiede, J., Polykova, Y. I., Timokhov, L. A., and Frolov, I. E., Moscow University Press, Moscow, Russia, 9 pp., 2009.

Fedorov, G., Nolan, M., Brigham-Grette, J., Bolshiyanov, D., Schwamborn, G., and Juschus, O.: Lake El'gygytgyn water and sediment balance components overview and its implications for the sedimentary record, Clim. Past Discuss., 8, 3977-4001, doi:10.5194/cpd-8-3977-2012, 2012.

Forman, S., Pierson, J., Gómez, J., Brigham-Grette, J., Nowaczyk, N., and Melles, M.: Luminescence geochronology for sediments from Lake El'gygytgyn, northeast Siberia, Russia: constraining the timing of paleoenvironmental events for the past $200 \mathrm{ka}$, J. Paleolimnol., 37, 77-88, doi:10.1007/s10933-006-9024-7, 2007.

Frank, U., Nowaczyk, N. R., Minyuk, P., Vogel, H., Ros'en, P., and Melles, M.: A $350 \mathrm{kyr}$ record of climate change from Lake El'gygytgyn, Far East Russian Arctic: refining the pattern of cli- 
mate modes by means of cluster analysis, Clim. Past Discuss., 8, 5109-5132, doi:10.5194/cpd-8-5109-2012, 2012.

Frederichs, T., von Dobeneck, T., Bleil, U., and Dekkers, M. J.: Towards the identification of siderite, rhodochrosite, and vivianite in sediments by their low-temperature magnetic properties, Phys. Chem. Earth, 28, 669-679, 2003.

Geiss, C. E. and Banerjee, S. K.: A multi-parameter rock magnetic record of the last glacial-interglacial paleoclimate from south-central Illinois, USA, Earth Planet. Sc. Lett., 152, 203216, doi:10.1016/S0012-821X(97)00133-7, 1997.

Holland, A. R., Wilkie, K., Petsch, S., Burns, S., and BrighamGrette, J.: Exploring bulk and 5 compound-specific isotopes in Lake El'gygytgyn sediments for evidence of anoxia and methane cycling over the Past $50 \mathrm{ka}$, Clim. Past Discuss., in preparation, 2013.

Kristensen, E. and Holmer, M.: Decomposition of plant materials in marine sediment exposed to different electron acceptors $\left(\mathrm{O}_{2}\right.$, $\mathrm{NO}_{3}^{-}$, and $\mathrm{SO}_{4}^{2-}$ ), with emphasis on substrate origin, degradation kinetics, and the role of bioturbation, Geochim. Cosmochim. Ac., 65, 419-433, doi:10.1016/S0016-7037(00)00532-9, 2001.

Langereis, C. G., Dekkers, M. J., de Lange, G. J., Paterne, M., and van Santvoort, P. J. M.: Magnetostratigraphy and astronomical calibration of the last 1.1 Myr from an eastern Mediterranean piston core and dating of short events in the Brunhes, Geophys. J. Int., 129, 75-94, doi:10.1111/j.1365-246X.1997.tb00938.x, 1997.

Layer, P. W.: Argon-40/argon-39 age of the El'gygytgyn impact event, Chukotka, Russia, Meteorit. Planet. Sci., 35, 591-599, doi:10.1111/j.1945-5100.2000.tb01439.x, 2000.

Lehmann, M. F., Bernasconi, S. M., Barbieri, A., and McKenzie, J. A.: Preservation of organic matter and alteration of its carbon and nitrogen isotope composition during simulated and in situ early sedimentary diagenesis, Geochim. Cosmochim. Ac., 66, 35733584, 2002.

Lozhkin, A. V., Anderson, P. M., Matrosova, T. V., and Minyuk, P. S.: The pollen record from El'gygytgyn Lake: implications for vegetation and climate histories of northern Chukotka since the late middle Pleistocene, J. Paleolimnol., 37, 135-153, doi:10.1007/s10933-006-9018-5, 2006.

Maher, B. A.: The magnetic properties of Quaternary aeolian dusts and sediments, and their palaeoclimatic significance, Aeolian Research, 3, 87-144, doi:10.1016/j.aeolia.2011.01.005, 2011.

Maher, B. A. and Thompson, R.: Paleoclimatic significance of the mineral magnetic record of the Chinese loess and paleosols, Quaternary Res., 37, 155-170, doi:10.1016/0033-5894(92)90079-X, 1992.

Melles, M., Brigham-Grette, J., Glushkova, O. Y., Minyuk, P., Nowaczyk, N., and Hubberten, W.: Sedimentary geochemistry of a pilot core from Lake El'gygytgyn - a sensitive record of climate variability in the East Siberian Arctic during the past three climate cycles, J. Paleolimnol., doi:10.1007/s10933-006-9025-6, 2007.

Melles, M., Brigham-Grette, J., Minyuk, P. S., Koeberl, C., Andreev, A., Cook, T., Fedorov, G., Gebhardt, C., HaltiaHovi, E., Kukkonen, M., Nowaczyk, N., Schwamborn, G., Wennrich, V., and El'gygytgyn Sci. Party: The Lake El'gygytgyn Scientific Drilling Project - Conquering Arctic challenges through continental drilling, Sci. Drill., 11, 29-40, doi:10.2204/iodp.sd.11.03.2011, 2011.
Melles, M., Brigham-Grette, J., Minyuk, P. S., Nowaczyk, N. R., Wennrich, V., DeConto, R., Anderson, P. M., Andreev, A. A., Coletti, A., Cook, T. L., Haltia-Hovi, E., Kukkonen, M., Lozhkin, A. V., Rosen, P., Tarasov, P., Vogel, H., and Wagner, B.: 2.8 million years of Arctic climate change from Lake El'gygytgyn, NE Russia, Science, 337, 315-320, doi:10.1126/science.1222135, 2012.

Minyuk, P. S., Brigham-Grette, J., Melles, M., Borkhodoev, V. Y., and Glushkova, O. Y.: Inorganic geochemistry of El'gygytgyn Lake sediments (northeastern Russia) as an indicator of paleomagnetic change for the last $250 \mathrm{kyr}$, J. Paleolimnol., 37, 123 133, 2007.

Minyuk, P. S., Subbotnikova, T. V., Brown, L. L., and Murdock, K. J.: Thermomagnetic properties of vivianite nodules, Lake El'gygytgyn, Northeast Russia, Clim. Past Discuss., 8, 49895027, doi:10.5194/cpd-8-4989-2012, 2012.

Nawrocki, J., Wøjcik, A., and Bogucki, A.: The magnetic susceptibility record in the Polish and western Ukrainian loess-palaeosol sequences conditioned by palaeoclimate, Boreas, 25, 161-169, 1996.

Nolan, M. and Brigham-Grette, J.: Basic hydrology, limnology, and meterology of modern Lake E'gygytgyn, Siberia, J. Paleolimnol., 37, 17-35, doi:10.1007/s10933-006-9020-y, 2007.

Nolan, M., Liston, G., Prokein, P., Brigham-Grette, J., Sharpton, V. L., and Huntzinger, R.: Analysis of lake ice dynamics and morphology on Lake El'gygytgyn, NE Siberia, using synthetic aperture radar (SAR) and Landsat, J. Geophys. Res., 107, 8162, doi:10.1029/2001JD000934, 2002.

Nowaczyk, N. R., Minyuk, P., Melles, M., Brigham-Grette, J., Glushkova, O., Nolan, M., Lozhkin, A. V., Stetsenko, T. V., Andersen, P. M., and Forman, S. L.: Magnetostratigraphic results from impact crater Lake El'gygytgyn, northeastern Siberia: a $300 \mathrm{kyr}$ long high-resolution terrestrial palaeoclimatic record from the Arctic, Geophys. J. Int., 150, 109-126, doi:10.1046/j.1365-246X.2002.01625.x, 2002.

Nowaczyk, N. R., Melles, M., and Minyuk, P.: A revised age model for core PG1351 from Lake El'gygytgyn, Chukotka, based on magnetic susceptibility variations tuned to northern hemisphere insolation variations, J. Paleolimnol., 37, 65-76, doi:10.1007/s10933-006-9023-8, 2007.

Nowaczyk, N. R., Haltia-Hovi, E. M., Ulbricht, D., Wennrich, V., Kukkonen, M., Rosen, P., Vogel, H., Meyer-Jacob, C., Andreev, A., and Lozhkin, A. V.: Chronology of lake El'gygytgyn sediments, Clim. Past Discuss., in preparation, 2013.

Schwamborn, G., Meyer, H., Fedorov, G., Schirrmeister, L., and Hubberten, H.-W.: Ground ice and slope sediments archiving late quaternary paleoenvironment and paleoclimate signals at the margins of El'gygytgyn Impact Crater, NE Siberia, Quaternary Res., 66, 259-272, doi:10.1016/j.yqres.2006.06.007, 2006.

Snowball, I. F.: Geochemical control of magnetite dissolution in subarctic lake sediments and the implications for environmental magnetism, J. Quaternary Sci., 8, 339-346, doi:10.1002/jqs.3390080405, 1993.

Tudryn, A., Tucholka, P., Gibert, E., Gasse, F., and Wei, K.: A late Pleistocene and Holocene mineral magnetic record from sediments of Lake Aibi, Dzungarian Basin, NW China, J. Paleolimnol., 44, 109-121, doi:10.1007/s10933-009-9391-y, 2010.

Vlag, P. A., Oches, E. A., Banerjee, S. K., and Solheid P. A.: The paleoenvironmental-magnetic record of the Gold Hill Steps loess section in central Alaska, Phys. Chem. Earth Pt. A, 24, 779-783, 
1999.

Wilkie, K. M.: Compound-Specific Hydrogen Isotopes of Lipid Biomarkers in Lake El'gygytgyn, Ne Russia, Ph.D. thesis, University of Massachusetts Amherst, USA, 2012.

Wilkie, K. M. K., Chapligin, B., Meyer, H., Burns, S., Petsch, S., and Brigham-Grette, J.: Modern isotope hydrology and controls on $\delta \mathrm{D}$ of plant leaf waxes at Lake El'gygytgyn, NE Russia, Clim. Past Discuss., 8, 3719-3764, doi:10.5194/cpd-8-37192012, 2012.
Wolfers, P., Fillion, G., Ouladdiaf, B., Ballou, R., and Rochette, P.: The pyrrhotite 32 K magnetic transition, Sol. St. Phen., 170, 174179, 2011. 